\begin{tabular}{c|c} 
Management and Business Review \\
\hline $\begin{array}{c}\text { MANAGEMENT \& } \\
\text { BUSINESS REVIEW }\end{array}$
\end{tabular}$\quad \begin{gathered}\text { Available at http://ejournal.unikama.ac.id/index.php/mbr } \\
\text { ISSN: } 2541-5808 \text { (online) }\end{gathered}$

\title{
Pengaruh kualitas pelayan dan costumer relationship management (CRM) terhadap kepuasan pelanggan
}

\section{Januarius Harmiyanto}

Program Studi Manajemen, Fakultas Ekonomika dan Bisnis, Universitas Kanjuruhan Malang, Indonesia

e-mail: Iharmiyanto@yahoo.co.id

$\begin{array}{ll}\text { Article Info: } \\ \text { Receive } & \text { : April } 2017 \\ \text { Revised } & : \text { Mei } 2017 \\ \text { Accepted } & : \text { Juni } 2017 \\ \text { Published } & : \text { Juni } 2017 \\ \text { DOI } & : \text { 10.21067/mbr.v1i2.4727 } \\ \text { Copyright } & : \text { Management and } \\ & \text { Business Review }\end{array}$

Keywords :

Kualitas pelayanan, Customer

Relationship Management, kepuasan pelanggan

\begin{abstract}
This study aims to determine the effect of service quality on customer satisfaction and customer relationship management on customer satisfaction at the PDAM Malang Regency. Respondents in this study amounted to 100 consumers who use the services of PDAM Malang Regency. The sampling technique used random sampling technique. The collected data were analyzed using multiple linear regression analysis techniques. Based on the research results, it is known that service quality has a significant influence on customer satisfaction, customer relationship management has a significant effect on consumer trust, service quality and customer relationship management simultaneously affects customer satisfaction.
\end{abstract}

\begin{abstract}
Abstrak: Penelitian ini bertujuan untuk mengetahui pengaruh kualitas pelayanan, terhadap kepuasan pelanggan dan pengauh Customer Relationship Management terhadap terhadap kepuasan pelanggan di Perusahaan Air Minum Kabupaten Malang. Responden dalam penelitian ini berjumlah 100 konsumen yang menggunakan jasa dari PDAM Kabupaten Malang. Teknik pengambilan sampel menggunakan teknik random sampling. Data yang terkumpul dianalisis menggunakan teknik analisis regresi linier berganda. Berdasarkan hasil penelitian diketahui bahwa kualitas pelayanan memiliki pengaruh secara signifikan terhadap kepuasan pelanggan, customer relationship management berpengaruh secara signifikan terhadap kepercayaan konsumen, kualitas pelayanan dan customer relationship management secara simultan berpengaruh terhadap kepuasan pelaggan.
\end{abstract}




\section{Pendahuluan}

Air merupakan kebutuhan pokok bagi setiap mahluk hidup di dunia ini termasuk manusia. Tanpa air, manusia akan mengalami kesulitan dalam melangsungkan hidupnya, maka dari itu pengolahannya harus diatur sedemikian rupa sehingga dapat dimanfaatkan secara efektif dan efesien. Air merupakan sumber daya nasional yang menyangkut hajat hidup orang banyak, maka pengolahannya diatur dan dipegang oleh pemerintah. Hal ini sesuai dengan UUD 1945 pasal 33 ayat (3), yang berbunyi sebagai berikut : "Bumi, air dan kekayaan alam yang terkandung didalamnya dikuasai oleh Negara untuk dipergunakan sebesarbesarnya kemakmuran rakyat".

Kualitas layanan yang baik dan berkualitas akan cendrung memberikan kepuasan yang lebih kepada pelanggan yang menggunakan jasa pada perusahan tersebut. Tanpa memperhatikan kualitas pelayanan maka jangan harap perusahan dapat terus mempertahankan image dimata pelanggan. Dengan mengutamakan pelayanan yang baik maka pelanggan akan memudahkan perusahan mencapai tujuan perusahan yaitu mencapai laba yang maksimal melalui peningkatan jumlah pembelian/pemakaian oleh pelanggan secara terus menerus. Tetapi meskipun telah dilakukan penambahan unit baru, dalam melakukan operasi pelayanan pihak PDAM kabupaten Malang sering mendapat keluhan dari masyarakat atau pelanggan. Keluhan masyarakat tentang sulitnya untuk mendapatkan air bersih serta masalah pendistribusian air yang sering mengalami kemacetan tampaknya masih menjadi kendala yang sepenuhnya belum dapat di atasi oleh pemerintah daerah dalam hal ini PDAM Kabupaten Malang.

Salah satu strategi yang dilakukan PDAM Kabupaten Malang dalam meningkatkan kualitas layanan terhadap pelanggan adalah dengan menerapkan Customer Relationship Marketing (CRM). Kotler \& Armstrong (2010) mengatakan bahwa CRM merupakan strategi yang digunakan dalam mengelola informasi yang rinci mengenai pelanggan dan secara berhati-hati mengelola semua interaksi pelangganuntuk memaksimalkan kesetiaan pelanggan. Buchari (2011) menyatakan Manajemen hubungan pelanggan atau yang biasa dikenal Customer Relationship Management (CRM) adalah suatu proses dalam mendapatkan, mempertahankan dan meningkatkan hubungan pelanggan yang menguntungkan dengan tujuan untuk menciptakan nilai pelanggan, sehingga pelanggan puas dan memaksimalkan keuntungan bagi perusahaan memperoleh dalam rangka memperoleh keunggulan bersaing (comparative advantage), memperhatikan mutu produk agar dapat memberikan kepuasan yang prima bagi pelanggan.

Menurut Buttle (2009) kepuasan pelanggan adalah respon berupa perasaan puas yang timbul karena pengalaman mengonsumsi suatu produk atau layanan, atau sebagian kecil dari pengalaman itu. Menurut Kotler \& Armstrong (2010) kepuasan pelanggan adalah sejauh mana anggapan kinerja prodak/jasa memenuhi harapan pelanggan. Menurut Zeithaml et al. (1990) mengemukakan bahwa kepuasan 
pelanggan adalah perasaan pelanggan terhadap suatu jenis pelayanan yang didapatkannya. Pelanggan akan merasa puas ketika jasa yang diterima sesuai dengan harapan meraka. Bertambahnya pelanggan yang menggunakan jasa PDAM setiap tahunnya diharapkan pelayanan dari pihak PDAM semakin baik dalam meningkatkan kualitas air bersih maupun pendistribusiannya. Pendistribusian air yang terhambat dapat berdampak negatif bagi masyarakat maupun bagi penyedia layanan air bersih itu sendiri. Tujuan penelitian untuk mengetahui pengaruh kualitas pelayanan berpengaruh terhadap kepuasan pelanggan di PDAM kabupaten malang; untuk mengetahui pengaruh Customer Relationship Management (CRM) terhadap kepuasan pelanggan di PDAM Kabupaten Malang, dan untuk mengetahui pengaruh kualitas pelayanan dan Customer Relationship Management (CRM) terhadap kepuasan pelanggan di PDAM Kabupaten Malang.

\section{Kualitas Layanan}

Menurut Kotler \& Keller (2007) kualitas pelayanan, yaitu perilaku produsen dalam rangka memenuhi kebutuhan dan keinginan konsumen atau pelanggan demi tercapainya kepuasan pada konsumen atau pelanggan itu sendiri. Kotler juga mengatakan bahwa perilaku tersebut dapat terjadi pada saat sebelum atau sesudah transaksi.

Penelitian Sutrisno (2015) tentang pengaruh kualitas layanan dan customer relationship management terhadap kepuasan pasien dan loyalitas pasien di Rumah Sakit Tingkat II Tentara Nasional Indonesia, menunjukan kualitas pelayan secara signifikan berpengaruh terhadap kepuasan dan loyalitas pasien, Customer Relationship Management (CRM) berpengaruh secara signifikan tehadap kepuasan dan loyalitas pasien dan kepuasan pasien secara signifikan berpengaruh terhadap loyalitas pasien di rumah sakit tingkat II TNI.

$\mathrm{H1}$ : Kualitas layanan berpengaruh terhadap kepuasan pelanggan

\section{Customer Relationship Management}

Customer relationship management merupakan konsep yang berfokus pada pemeliharaan hubungan dengan pelanggan untuk membangun hubungan jangka panjang dan menguntungkan dengan pelanggan, CRM menggambarkan bagaimana perusahaan berinteraksi dan secara aktif mengelola hubungan dengan pelanggan (Buttle, 2009). Kotler \& Armstrong (2010) menyatakan bahwa CRM adalah seluruh proses dalam membangun dan menjaga hubungan yang menguntungkan dengan pelanggan melaluinilai dan kepuasan yang tinggi. Secara urnum dapat dinyatakan bahwa CRM bertujuan untuk mengembangkan hubungan menguntungkan dan mewujudkan nilai bagi para konsumen sasaran secara profitable dengan mengintegrasikan proses dan fungsi internal dengan semua jaringan eksterna (Buttle, 2009). 
Penelitian Kalalo (2013) tentang customer relationship management dan kualitas pelayanan pengaruhnya terhadap loyalitas konsumen PT. Matahari Dept. Store, Manado menunjukan bahwa Customer Relationship Management (CRM) dan Kualitas Pelayanan berpengaruh signifikan terhadap loyalitas konsumen. Berdasarkan analisis menunjukan bahwa variabel customer relationship management (CRM) dan kualitas pelayanan mempunyai pengaruh yang positif terhadap loyalitas konsumen.

Nurcahyo \& Nur'ainy (2014) menyatakan bahwa customer relationship management yang baik mampu meningkatkan nilai pelanggan dan kualitas pelayanan, selanjutnya akan meningkatkan kepuasan pelanggan. Penelitian Farida (2017) menyatakan bahwa Customer Relationship Management berpengaruh terhadap kepuasan, Customer Relationship Management berpengaruh tidak langsung terhadap loyalitas investor melalui kepuasan. Selanjutnya kualitas layanan terhadap kepuasan investor pada PT Danareksa Medan.

$\mathrm{H} 2$ : Customer relationship management berpengaruh terhadap kepuasan pelanggan

\section{Kepuasan Pelanggan}

Kepuasan bisa diartikan sebagai upaya pemenuhan sesuatu atau membuat sesuatu memadai Tjiptono \& Chandra (2011). Secara tradisional pelanggan diartikan orang yang membeli dan menggunakan produk. Pandangan ini menyimpulkan bahwa pelanggan adalah orang yang berinteraksi dengan perusahaan sebelum proses produksi selesai.

Penelitian Iriandini (2015) tentang pengaruh customer relationship management (CRM) terhadap kepuasan pelanggan dan loyalitas pelanggan, CRM berpengaruh terhadap kepuasan dan loyalitas pelanggan. Selanjutnya penelitian Dewi (2015) membuktikan bahwa CRM memiliki pengaruh positif terhadap kepuasan konsumen dan CRM berpengaruh positif terhadap loyalitas. Kepuasan pelanggan tidak berpengaruh terhadap loyalitas pelanggan.

\section{Metode}

Jenis penelitian ini adalah jenis penelitian asosiatif, yaitu penelitian yang bersifat hubungan antara dua variabel atau lebih. Explanatory research dalam penelitian ini digunakan untuk menguji hipotesis tentang ada tidaknya pengaruh kualitas layanan dan Customer Relationship Management terhadap kepuasan pelanggan pada Perusahaan Daerah Air Minum Kab. Malang.

Populasi dalam penelitian ini adalah konsumen yang menggunakan jasa PDAM Kab. Malang. Peneliti menggunakan metode random sampling yaitu pengambilan sampel dari anggota populasi secara acak tanpa memperhatikan strata 
(tingkatan). Jumlah sampel ditentukan dengan menggunakan rumus yang dikemukakan oleh Slovin, diperoleh 100 responden.

Teknik pengumpulan data menggunakan kuesioner yang disusun dengan Skala Likert 5 poin, dan telah diuji validitas dan reliabilitasnya. Teknik analisis data menggunakan Regresi Linier Berganda.

\section{Hasil}

Analisis regresi linier berganda digunakan untuk mengetahui seberapa besar pengaruh variabel bebas yaitu kualitas pelayanan (X1)Customer Relationship Management (X2). Hasil analisis terlihat dalam tabel 1.

Tabel 1

Ikhtisar Output Regresi Linier Berganda

\begin{tabular}{|c|c|c|c|c|c|}
\hline \multirow[t]{2}{*}{$\begin{array}{l}\text { Variabel } \\
\text { Independent }\end{array}$} & \multicolumn{2}{|c|}{$\begin{array}{l}\text { Unstandardized } \\
\text { Coefficients }\end{array}$} & \multirow[t]{2}{*}{ Beta } & \multirow[t]{2}{*}{ t-hitung } & \multirow[t]{2}{*}{ Sign. $T$} \\
\hline & B & Std.Error & & & \\
\hline (Constant) & 4.425 & 2.292 & - & 1.931 & 0,056 \\
\hline $\begin{array}{l}\text { Kualitas Pelayanan } \\
(X 1)\end{array}$ & 0,408 & 0,059 & 0,601 & 6,926 & 0,000 \\
\hline CRM $(X 2)$ & 0,468 & 0,138 & 0,295 & 3,395 & 0,001 \\
\hline R Square $\left(\mathrm{R}^{2}\right)$ & 0,728 & & & & \\
\hline Adusted R Square & 0,723 & & & & \\
\hline F-hitung & 30.116 & & & & \\
\hline Sign-F & 0.000 & & & & \\
\hline
\end{tabular}

Variabel Dependent $=$ Kepuasan Pelanggan $Y$

Sumber : Output SPSS, diolah 2017

Variabel kualitas pelayanan (X1) memiliki nilai koefisien positif sebesar 0,408 dan menyatakan bahwa setiap satuan variable kualitas pelayanan akan memberikan pengaruh sebesar 0.408 terhadap kepuasan pelanggan apabila variable lainnya tetap. Data tersebut menunjukan bahwa kualitas pelayanan berpengaruh positif (searah) terhadap kepuasan pelanggan artinya semakin sesuai kualitas pelayanan yang diberikan maka semakin tinggi pula kepuasan yang pelanggan dapatkan.

Hasil analisis menjelaskan nilai signifikan yang didapatkan oleh variabel kualitas sebesar 0,000 lebih kecil dari taraf signifikan yang ada yaitu 0,05 dan dengan ini disimpulkan jika adanya pengaruh signifikan antara kualitas layanan terhadap kepuasan pelanggan dan hipotesis 1 diterima.

Variabel Customer Relationship Management (X2) memiliki nilai koefisien positif sebesar 0,468 dan menyatakan bahwa setiap satua variable Customer 
Relationship Management memberi pengaruh sebesar 0,468 terhadap kepuasan pelanggan apabila variable lainnya tetap. Data tersebut menunjukan bahwa semakin baik pengelolaan Customer Relationship Management atau manajemen hubungan pelanggan dilakukan maka semakin puas juga pelayanan yang didapatkan oleh pelanggan PDAM Kabupaten Malang.

Hasil analisis menjelaskan nilai signifikan yang didapatkan oleh variabel Customer Relationship Management sebesar 0,001yang mana hasil ini lebih kecil dari taraf signifikan yang ada yaitu 0,05 dan dengan ini disimpulkan jika adanya pengaruh signifikan antara Customer Relationship Management terhadap kepuasan pelanggan dan hipotesis 2 diterima.

\section{Pembahasan}

\section{Pengaruh Kualitas Pelayanan Terhadap Kepuasan Pelanggan}

Deskripsi data dan analisis hasil penelitian variabel kualitas pelayanan yang telah dijelaskan pada bab sebelumnya bahwa kualitas pelayanan memeliki pengaruh yang signifikan terhadap kepuasan pelanggan, sebab nilai yang didapat dari hasil output analisis SPSS sangat besar dibandingkan dengan variabel Customer Relationship Management. Kualitas pelayanan yang positif terbentuk dibenak pelanggan akan meningkatkan nilai kepuasan pelanggan di PDAM Kabupaten Malang.

\section{Pengaruh Customer Relationship Management Terhadap Kepuasan Pelanggan}

Berdasarkan hasil analisis diketahui bahwa variabel Customer Relationship Management berpengaruh positif dan signifikan terhadap kepuasan pelanggan. Hal ini menunjukan bahwa Customer Relationship Management mampu mempengaruhi kepuasan pelangganpada PDAM Kabupten Malang. Sistem Customer Relationship Management yang telah diterapkan oleh PDAM Kabupaten Malang mampu meningkatkan kepuasan pelanggan. Hasil distribusi frekuensi variabel Customer Relationship Management terlihat bahwa tingkat kemampuan karyawan dalam menjaga hubungan yang baik dengan pelanggan dalam memberikan pelayanan mampu meningkatkan kepuasan pelanggan pada PDAM Kabupaten Malang.

Temuan penelitian ini mendukung penelitian Sutrisno (2015) bahwa kualitas pelayan sebagai faktor yang berpengaruh terhadap kepuasan, serta hasil penelitian Iriandini (2015) bahwa customer relationship management (CRM) berpengaruh terhadap kepuasan pelanggan. Demikian pula sejalan dengan penelitian Hartanto (2010) yang menyatakan bahwa kualitas layanan perbankan berpengaruh terhadap

kepuasan nasabah. Hasil penelitian juga mendukung penelitian Nurcahyo \& Nur'ainy (2014) menyatakan bahwa customer relationship management yang baik 
mampu meningkatkan nilai pelanggan dan kualitas pelayanan, selanjutnya akan meningkatkan kepuasan pelanggan.

\section{Kesimpulan}

Berdasarkan hasil penelitian dapat ditarik kesimpulan kualitas pelayanan berpengaruh positif dan signifikan terhadap kepuasan pelangggan di Perusahan Air Minum Kabupaten Maalan. Hal ini muncul karena banyaknya pelanggan yang menggunakan jasa PDAM Kabupaten Malang merasakan kenyamanan ketika melakukan proses pelayanan dimana mereka ditangani oleh para pegawai atau para karyawan yang berpenampilan rapi ketika memberikan pelayanan. Temuan lain menunjukkan bahwa Customer Relationship Management berpengaruh positif dan signifikan terhadap kepuasan pelanggan di Perusahan Daerah Air Minum Kabupaten Malang. Hal ini muncul karena tingkat kemampuan karyawan dalam menjaga hubungan yang baik dengan pelanggan dalam memberikan pelayanan mampu meningkatkan kepuasan pelanggan pada PDAM kabupaten Malang. Kulaitas pelayanan dan Customer Relationship Management secara bersama-sama berpengaruh terhadap kepuasan pelanggan, meskipun kualitas pelayanan memeliki pengaruh yang lebih dominan.

Penelitian yang akan datang perlu memperhatikan beberapa hal, bahwa meski kualitas pelayanan dan CRM memiliki nilai yang positif dan signifikan terhadap kepuasan pelanggan dalam pernytaann masih ada prosentase terendah dari masing-

masing variabel. Oleh karena itu peneliti yang akan datang bisa menambahkan beberapa variabel tambahan.

\section{Daftar Pustaka}

Buchari, A. (2011). Manajemen pemasaran dan pemasaran jasa. Bandung: Alfabeta.

Buttle, F. (2009). Customer relationship management: Concepts and technology. Sydney: a Butterworth-Heinemann.

Dewi, A. A. C. (2015). Pengaruh Customer Relationship Management (CRM) Terhadap Customer Satisfaction Dan Customer Loyalty Pada Pelanggan Sushi Tei Surabaya. Jurnal Strategi Pemasaran, 3(1), 1-9.

Farida, T. (2017). Pengaruh Customer Relationship Management Dan Kualitas Layanan Terhadap Kepuasan Dan Loyalitas Investor PT Danareksa Medan. Jurnal Ilmiah Manajemen Dan Bisnis, 17(1).

Hartanto, J. T. (2010). Analisis Pengaruh Kualitas Pelayanan Jasa Perbankan Terhadap Kepuasan Nasabah (Study Kasus Pada PD. BPR Bank Jogja). Program Magister Manajemen Universitas Gunadarma. 
Iriandini, A. P. (2015). Pengaruh customer relationship management (CRM) terhadap kepuasan pelanggan dan loyalitas pelanggan (Survey pada Pelanggan PT. Gemilang Libra Logistics, Kota Surabaya). Jurnal Administrasi Bisnis, 23(2).

Kalalo, R. E. (2013). Customer relationship management dan kualitas pelayanan pengaruhnya terhadap loyalitas konsumen PT. Matahari Dept. Store, Manado. Jurnal EMBA: Jurnal Riset Ekonomi, Manajemen, Bisnis Dan Akuntansi, 1(4).

Kotler, P., \& Armstrong, G. (2010). Principles of marketing. Pearson education.

Kotler, P., \& Keller, K. L. (2007). Manajemen Pemasaran. In Jakarta: Erlangga. Erlangga.

Nurcahyo, B., \& Nur'ainy, R. (2014). The Role of Customer Relationship Management on Customer Value and Service Quality in Improving Customer Satisfaction.

Sutrisno, S. (2015). Pengaruh Kualitas Layanan, dan Customer Relationship Management Terhadap Kepuasan Pasien dan Loyalitas Pasien di Rumah Sakit Tingkat II Tentara Nasional Indonesia. JMM17: Jurnal Ilmu Ekonomi Dan Manajemen, 2(02).

Tjiptono, F., \& Chandra, G. (2011). Service, Quality E Satisfaction Edisi 3. Yogyakarta: Andi Offset.

Zeithaml, V., Parasuraman, A., \& Berry, L. L. (1990). Delivering quality service: Balancing customer perceptions and expectations. New York: The Free Press. 